\title{
The Role of Herpes Virus Infection in Changing the Cytokine Status in the Body of a Pregnant Woman
}

\author{
Dobrokhotova $\mathrm{YE}^{1 *}$, Savchenko $\mathrm{TN}^{1}$, Alyoshkin $\mathrm{VA}^{2}$, Afanasyev $\mathrm{SS}^{2}$ and Agayeva $\mathrm{MI}^{1}$ \\ ${ }^{1}$ Department of Obstetrics and Gynecology, Russian National Research Medical University, Russia \\ ${ }^{2}$ Moscow Research Institute of Epidemiology and Microbiology, GN Gabrichevsky, Russia \\ ${ }^{3}$ Research Center Institute Immunology of the Federal Medical and Biological Agency of Russia, Russia
}

Submission: April 20, 2017; Published: July 03, 2017

*Corresponding author: Dobrokhotova YE, Department of Obstetrics and Gynecology, Russian National Research Medical University, Russia, Tel: 89-0372-263-99; Email: pr.dobrohotova@mail.ru

\begin{abstract}
The article is dedicated to researching the effect of herpes virus infection (HVI) on the level of immuno regulatory cytokines during pregnancy

Purpose: Studying cytokine reactions at the local and systemic levels in pregnant women with various HVI runs.

Materials and methods: 55 patients in the first half of gestation were tested, for whom, in addition to the routine research methods, polymerase chain reaction (PCR) of blood and cervix scrape, solid phase enzyme multiplied immunoassay (sp EMIA) of blood serocity, as well as enzyme multiplied immunoassay (EMIA) of blood plasma and cervical secretion, were carried out.

Result: Group I (main group) included 35 patients with active HVI, Group II (check group) included 20 patients with latent HVI run. The research of the cytokine status has showed accurate ominance of pro-inflammatory cytokine concentration over anti-inflammatory cytokine levels in blood plasma and cervical channel secretion of HVI. The most clearly manifested changes of the cytokine status took place at the local level, while failure of vicarious reserves led to implementation of systemic immune response and pregnancy failure.
\end{abstract}

Keywords: Infanticide; Bottlenose dolphin; Spinner dolphin; Interaction; Tooth mark; Acoustic; behavior; Indian ocean

\section{Introduction}

Herpes viruses (HV) are widely spread among the human population. They can affect nearly all organs and body systems of the host, causing latent, acute and chronic forms of infection. HVI is of special importance during pregnancy, upto30\% spontaneous abortions at early stages and up to $50 \%$ at later stages of gestation are a consequence of HVI effect [1,2]. Two stages can be identified in the HVI lifecycle:

A. The lytic stage characterized by active reduplication of virus DNA and

B. The latent stage when virus stays in the body in the form of sub-virus structures [2].

The in born immunity system is the body's first line of defense at primary HV contamination, reactivation of chronic and latent forms of HVI. Regulation of immune response is carried out by generating pro- and anti-inflammatory cytokines. Primary HV contamination and/or latent and chronic HVI reactivation cause development of early cytokine reactions which are a basis of natural immune response [3]. Developmen to fimmune responsefully suppresses multiplication of viruses and prevents their dissemination, however, during pregnancy sensibility to non-germ antigens decreases due to physiological Immuno depression which leads to activation of chronic virus infection. Research of the cytokine status in pregnant women with various HVI runs will allow optimizing HVI diagnostics and therapy methods, as well as determining methods of conditioning.

\section{Purpose}

Studying cytokine regulation of immune response at the local and systemic levels in pregnant women with various runs of HVI.

\section{Materials}

We have carried out a clinical and lab research of 55 (100\%) patients of the I, II trimesters of gestation (out of whom 37 $(67.3 \%)$ patients were hospitalized into gynecology hospital departments, complaining about blood egesting from the genital tract and $18(32.3 \%)$ pregnant women with physiological run 


\section{Global Journal of Reproductive Medicine}

of gestation process examined in maternity welfare centers). Theageofpregnantwomenvariedfrom 18 to 33 , the average age was $27 \pm 7.5$.Using the solid phase enzyme multiplied immunoassay (sp EMIA), Immuno globulins IgG and IgM in blood serum were assessed to HSV 1,2, CMV and EBV; using polymerase chain reaction (PCR), virus DNA in fragments of peripheral blood and endocervix cells crape was assessed. By way of spEMIA using Cytokine LTD's test systems levels of IL4, 8, 10, IFN- $\gamma$, TNF-ain blood plasma and cervical slime were tested, IL17 concentration and transforming growth factor- $\mathrm{b}$ (TGF-b)in blood plasma when using Biokhimmac test systems were assessed. All the data obtained were analyzed using Intel (R) Core Duo CPU personal computer with a package of applied Microsoft Excel software, Windows 10 version, Data Analysis section, Descriptive Statistics division, for statistical data manipulation. The statistical data manipulation was carried out using STATISTICA standard package, version 8.0, and STATISTICA 13.0 trial version. The critical confidence level, when checking statistical hypotheses, was assumed equal to $\mathrm{p}<0.05$.The comparative analysis of quantitative data, complying with the distribution law, was carried out using calculation of Student's t-criterion parameter numbers. Their description is given as mean (M), standard deviation (S). To estimate connection between number variables with Gaussian distribution the linear correlation analysis with calculation of Pearson factor (r) was used.

\section{Result}

Based on the clinical and laboratory test data diagnostic HVI activation markers were found in 35 pregnant women. Out of them, IgM to cytomegalovirus (CMV) were found in blood serum of $8(14.5 \%)$ patients, Epstein-Barr virus (EBV) - in5 (9\%), herpes simplex virus - in $4(11.4 \%)$ to viruses of herpes simplex of the 1st and 2nd types (HSV 1,2). Using PCR diagnostics of blood fragments, EBV DNA was found in 9 (16.3\%) pregnant women, CMV DNA -in 7 (12.7\%) HSV 1,2DNA- in 5 (9\%) tested women. When using PCR diagnostics of cervical channel epithelium cell scrape, CMV was found in 8 (14.5\%) women and HSV 1,2- in 4 (11.4\%) women. HVI activation marker association was noted in $30 \%$ cases. Clinical manifestations of HVI in the form of labial herpes could be seen in $3(8.5 \%)$ patients, genitaliaherpeswasfoundin2 (5.7\%) pregnant women, acute upper respiratory like symptoms were noted in 10 (28.5\%) women, asymptomatic form of herpes infection was noted in all the rest of the patients.

Table 1: Concentrations of cytokines in blood plasma in the examined women.

\begin{tabular}{|c|c|c|c|}
\hline \multirow{3}{*}{ Cytokines } & \multirow{2}{*}{\multicolumn{2}{|c|}{$\begin{array}{c}\text { Groups of the Examined }(\mathrm{N}=55) \\
\text { Mean Values }(\mathrm{M} \pm \mathrm{S}) \mathrm{pg} / \mathrm{ml}\end{array}$}} & \multirow{3}{*}{ Reliability, P } \\
\hline & & & \\
\hline & group-I $(n=35)$ & group-II $(n=20)$ & \\
\hline TNF-a & $9,13 \pm 1,3$ & $0,0 \pm 0,0$ & $0,00033^{*}$ \\
\hline IL-10 & $60,28 \pm 7,6$ & $119,04 \pm 15,1$ & $\mathrm{p}<0,0001^{*}$ \\
\hline ИФН- $\gamma$ & $88,71 \pm 17,1$ & $78,27 \pm 22,3$ & 0,4717 \\
\hline IL-4 & $22,51 \pm 8,2$ & $16,1 \pm 3,2$ & 0,16222 \\
\hline IL-8 & $785,5 \pm 28,4$ & $831,12 \pm 20,0$ & 0,86099 \\
\hline TGF-b & $8016,65 \pm 19,1$ & $8058,04 \pm 17,2$ & 0,72869 \\
\hline IL-17 & $0 \pm 0$ & $0,75 \pm 1,47$ & 0,32481 \\
\hline
\end{tabular}

Note: *Reliability of the differences between the $1^{\text {st }}$ and $2^{\text {nd }}$ group $(\mathrm{P}<0.05)$.

Table 2: Concentrations of cytokines in cervical mucus in the examined pregnant women.

\begin{tabular}{|c|c|c|c|}
\hline \multirow{3}{*}{ Cytokines } & \multirow{2}{*}{\multicolumn{2}{|c|}{$\begin{array}{c}\text { Groups of the Examined }(\mathrm{N}=55) \\
\text { Mean Values }(\mathrm{M} \pm \mathrm{S}) \mathrm{pg} / \mathrm{ml}\end{array}$}} & \multirow{3}{*}{ Reliability, P } \\
\hline & & & \\
\hline & group-I $(n=35)$ & group-II $(n=20)$ & \\
\hline TNF-a & 0 & $0,0 \pm 0,0$ & 0,12249 \\
\hline IL-10 & $6,7 \pm 8,1$ & $25,4 \pm 7,04$ & $\mathrm{p}<0,0001^{*}$ \\
\hline ИФН- $\gamma$ & $32,8 \pm 4,6$ & $20,6 \pm 4,3$ & $0,00037^{*}$ \\
\hline IL-4 & $13,38 \pm 2,1$ & $24,7 \pm 3,8$ & $\mathrm{p}<0,0001^{*}$ \\
\hline IL-8 & $559,89 \pm 22,9$ & $260,2 \pm 10,5$ & $0,02022^{*}$ \\
\hline TGF-b & $8016,65 \pm 19,1$ & $8058,04 \pm 17,2$ & 0,72869 \\
\hline IL-17 & $0 \pm 0$ & $0,75 \pm 1,47$ & 0,32481 \\
\hline
\end{tabular}

Note: *Reliability of the differences between the I-st and II-nd group $(\mathrm{P}<0.05)$. 


\section{Global Journal of Reproductive Medicine}

Group I (main group) included 35 (63.6\%) pregnant women, in whom direct (finding of viruses) and indirect (presence of IgM to HV) signs of virus replication. The check group (Group II) included20 (36.4\%) pregnant women with latent infection, in whom, per the clinical and lab test data, specific IgG to HV in low statistical titers were identified with no clinical and lab signs of HVI activation. When studying the cytokine status of the patients in the research groups, it was found out that in pregnant women of Group I the balance between anti-inflammatory and pro-inflammatory cytokines at the systemic and local levels was imbalanced in favor of the latter (Table 1\&2). When comparing cytokine levels in blood plasma, reliable increase of TNF-a in Group I, comparing with Group II $(9.13 \pm 1.3$ and $0.0 \pm 0.0 \mathrm{pg} / \mathrm{ml}$ respectively) $(\mathrm{P}<0.05)$, was noted.ConcentrationofIL10in blood plasma also had reliable variances in the tested groups being $60.28 \pm 7.6 \mathrm{pg} / \mathrm{ml}$ for the women in Group I and $119.04 \pm 15.1 \mathrm{pg} /$ $\mathrm{ml}$ for the patients in Group II $(\mathrm{P}<0.05)$. Level so fI $\mathrm{FN}-\gamma$ in blood plasma of the tested women didn't have any statistically reliable variances, however, its concentration in the main group was somewhat higher than in the comparison group. The absence of statistically important variances of IFN- $\gamma$ level in the systemic immune response of pregnant women in the tested groups can be a result of Immuno depressive effect of HV on the IFN system and is manifested in suppression of interferon genesis by leucocytes followed by lowering of IFN- $\gamma$ serum level $[4,5]$. WhencomparingconcentrationlevelsofIL8, TGF $\beta$, IL-17 in blood plasma of the tested patients, also nor eliable variances were found, with TGF- $\beta$ level in pregnant women of Group I being somewhat higher than in the patients of Group II which can be a result of activation of adaptation and vicarious mechanisms aimed at suppressing the bodily inflammatory reaction, as well as development and maintenance of immunological tolerance to fetus antigens. It should be noted that IL17 concentration in blood plasma of all the tested women corresponded to zero values. IL17 was identified relatively recently, due to which it is less studied. It is known that it is a pro-inflammatory cytokine and is synthesized by Th17 which is generated by reverse differentiation of Th0. It is also known that modulation of immune response byTh1 andTh2 prevents differentiation of naiveT-lymphocytes inTh17; IL17 antagonists are IFN- $\gamma$ and TGF-b, with high concentration of IL17 stimulating synthesis of endogenic IFN [4]. Considering the above data, absence of IL17 in plasma of the tested patients can be related to the fact that induction of immune response was carried out through Th1 andTh 2 agitation with a short period of existence of IL17, as well as due to changes in the immune system during pregnancy. When studying cytokine regulation of the immune response at the local level, dropping of IL4, 10concentration levels in cervical mucus of Group I patients, comparing with Group II patients (IL10$6,7 \pm 8,1$ and $25,4 \pm 7,04 \mathrm{pg} / \mathrm{ml}$ respectively; IL4 $-13.38 \pm 2.1$ and $24,7 \pm 3,8 \mathrm{pg} / \mathrm{ml}$ respectively) could be seen. Increase of IFN- $\gamma$, IL8 concentration in cervical channel secretion of the pregnant women in the main group versus the comparison group could be seen (Table 3).

Table 3: Levels of cytokines in blood plasma in various pregnancy.

\begin{tabular}{|c|c|c|c|c|c|c|}
\hline \multirow{2}{*}{$\begin{array}{c}\text { The Course of } \\
\text { Pregnancy }\end{array}$} & \multicolumn{7}{|c|}{ Cytokines (mean M + S)pg/ml } & IL10 & Il8 \\
\cline { 2 - 7 } & TNF-a & IFN- $\gamma$ & TGF-b & IL4 & $120+15,1$ & $780+35,1$ \\
\hline $\begin{array}{c}\text { Physiological } \\
\text { course of } \\
\text { pregnancy }\end{array}$ & 0 & $57,5+5,5$ & $6979+19,8$ & $24,3+3,2$ & $60+10,1^{*}$ & $835+15,3$ \\
\hline Still pregnancy & $9,13 \pm 4,3^{*}$ & $80,3+11,5^{*}$ & $13886+18,5^{*}$ & $18,3+2,2$ & $55+5,5^{*}$ & $840+12,4$ \\
\hline $\begin{array}{c}\text { Spontaneous } \\
\text { abortion }\end{array}$ & 0 & $75,1+6,5^{*}$ & $12478+16,1^{*}$ & $19,1+2,5$ & $70,1+9,5$ & $810+11,1$ \\
\hline $\begin{array}{c}\text { Inevitable } \\
\text { abortion }\end{array}$ & 0 & $68,1+7,8$ & $9829+13,1$ & $22,1+3,1$ & 7 \\
\hline
\end{tabular}

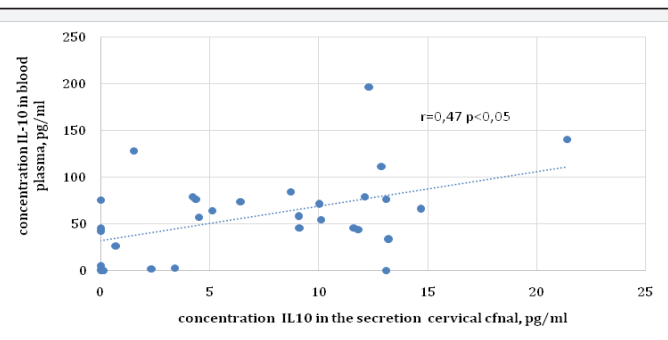

Figure 1: Correlation analysis of IL-10 concentration in blood plasma and cervical secretion among patients of group I.

We have carried out a correlation analysis between the levels of pro-and anti-inflammatory cytokines in blood plasma and cervical mucus of the tested patients. Direct correlation link of average power $(r=0,47)$ between IL10 level in blood plasma and in cervical mucus in patients of the main group was found
(Figure 1). When assessing interrelation of other cytokines, no correlation was found. The absence of strong correlation link between the level of cytokines in blood plasma and cervical channel secretion indicates the ability of autonomous regulation of immune response at the local level. Implementation of protection mechanisms of genitaliamu couscoats assists in limitation of infection inflammatory process prevents dissemination of virus agents and appearance of circulating cell-bound immune complexes inherent to systemic immune response [5,6].

Despite a high frequency of finding viral antigens in the systemic blood flow of the patients in the main group, changes of the immune system are more clearly manifested at the local level which testifies an important role of the local immune response in 


\section{Global Journal of Reproductive Medicine}

anti-contagious protection during pregnancy. Analyzing the run and the outcomes of the current pregnancy of the tested patients, we have drawn the following conclusions: a high percentage of missed abortions were diagnosed in Group I- 8 patients (22.8\%), while no cases of stagnant pregnancy were noted in Group II (Figure 2). The spontaneous abortion in both groups was about the same and equaled to $11.4 \%$ cases in the main group and $10 \%$ cases in the check group. A threatened abortion was diagnosed at $17(48.5 \%)$ patients with active HVI run and threatened abortion with latent HVI was diagnosed at $6(30 \%)$ patients. Physiological course of pregnancy was identified at $6(17.1 \%)$ patients of the main group and at $12(60 \%)$ patients of the control group.

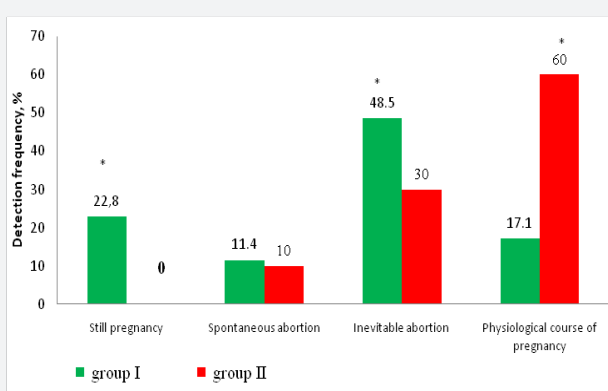

Figure 2: Clinical characteristics of the course of pregnancy. Note: *Reliability of the differences between the 1-st and 2-nd group $(P<0.05)$.

Table 4: Levels of cytokines in cervical mucus in different pregnancy.

\begin{tabular}{|c|c|c|c|c|c|}
\hline \multirow{2}{*}{$\begin{array}{c}\text { The Course of } \\
\text { Pregnancy }\end{array}$} & TNF-a & ИФН- $\boldsymbol{4}$ & Ил4 & Ил10 & Ил8 \\
\cline { 2 - 6 } & 0 & $20,5+4,3$ & $24,3+3,2$ & $25,3+4,2$ & $250+105,5$ \\
\hline $\begin{array}{c}\text { Physiological course } \\
\text { of pregnancy }\end{array}$ & 0 & $30,5+3,5^{*}$ & $10,3+2,2^{*}$ & $6,5+3,2^{*}$ & $560,9+220^{*}$ \\
\hline Still pregnancy & 0 & $28+2,6^{*}$ & $12,1+2,5^{*}$ & $8,5+3,5^{*}$ & $540+125,4^{*}$ \\
\hline Spontaneous abortion & 0 & $25+3,4$ & $15,1+3,1$ & $15,3+4,3$ & $310+151,1$ \\
\hline Inevitable abortion & 0 & & & \\
\hline
\end{tabular}

Note: *Reliability of differences $(p<0.05)$.

Based on the results obtained, the following conclusions were drawn: HVI potentiates a high risk of gestation complications. When studying the cytokine status of pregnant women with latent run of HVI, significant cytokine regulation disorders of immune response were detected. Activation of latent forms of HVI during pregnancy is a trigger factor for switching the immune agitation from Th2 over to Th1, with implementation of immune response taking place predominantly at the local level. Development of systemic immune response, in our opinion, is a consequence of vicarious and adaptive mechanism failure and represents a big threat of a developing pregnancy failure. The reason for systemic inflammatory reaction can be presence of autoimmune diseases, immuno depression due to long-lasting HV persistence.
We have also carried out a cytokine concentration analysis at the systemic and local regulation levels in various pregnancy runs (Table $3 \& 4$ ). Based on the results of this analysis, an imbalance of pro-inflammatory and anti-inflammatory cytokines, both at the local and systemic levels of immune response in the persons with failed pregnancy, was identified. At that, it should be noted that in patients with incipient abortions cytokine reactions were more clearly manifested at the systemic level. In the group of patients with aborted pregnancy, manifested increase of pro-inflammatory cytokine concentration in blood plasma was assessed more reliably. In $75 \%$ cases, in blood plasma of the patients with stagnant pregnancy TNF-a reaches the values of $9.13 \pm 4.3 \mathrm{pg} / \mathrm{ml}$, in the rest of the cases the TNF-a level doesn't exceed zero values. High concentrations of TGF- $\beta$ anti-inflammatory cytokine in blood plasma of the patients with aborted pregnancy, most likely, was a result of the compensatory reaction aimed at suppression of systemic inflammation (Table 3 ). When studying local immune response, the following cytokine regulation disorders manifested in the dominance of synthesis of pro-inflammatory cytokines over anti-inflammatory cytokines were identified. Maximum concentrations of pro-inflammatory cytokines in cervical secretion against minimum values of antiinflammatory cytokines were detected in the patients with aborted pregnancy [7].

\section{Conclusion}

Thus, we have detected that HVI activation assists in more clearly manifested changes of the immune status at the local level while a failure of compensation abilities and inclusion of systemic immune response assists in abortion of pregnancy. Due to the above, studying the cytokine status during pregnancy, as well as at the stages of preconception preparation, will assist information of complicated gestation risk groups and will allow finding out whether there is a requirement for immuno corrective therapy.

\section{References}

1. Buchanan R, Bonthius DJ (2012) Measles virus and associated central nervous system sequelae. Semin Pediatr Neurol 19(3): 107-114. 
2. Savchenko TN, Aleshkin VA, Agaeva MI (2014) Pregnancy and EPSTEIN- BARR virus-inducted infection. Russian Bulletin of ObjectiveGynecologist 5: 35-39.

3. Savchenko TN, Melnikov AV (2011) Indices of local immunity and microbiocenosis of genital tracts with polyps of the cervical canal. The difficult patient 9(8-9): 16-20.

4. Duell BL, Tan CK, Carey AJ, Wu F, Cripps AW, et al. (2012) Recent insights into microbial triggers of interleukin-10 production in the host and the impact on infectious disease pathogenesis. FEMS Immunology and Medical Microbiology 64(3): 295-313.

This work is licensed under Creative Commons Attribution 4.0 Licens

DOI: 10.19080/GJORM.2017.01.555568
5. Carville A, Mansfield KG (2008) Comparative pathobiology of macaque lymphocryptoviruses. Comp Med 58(1): 57-67.

6. Dobrokhotova YE, Jobava EM, li AD (2006) Some aspects of anticoagulant therapy thromboxy states in pregnant women with thrombotic complications and injury pregnance. Medical matter, pp. 59-68.

7. Milovanovic M, Drozdenko G, Weise C, Babina M, Worm M (2010) Interleukin-17A Promotes IgE Production in Human B Cells. J Invest Dermatol 130(11): 2621-2628.

\section{Your next submission with Juniper Publishers will reach you the below assets}

- Quality Editorial service

- Swift Peer Review

- Reprints availability

- E-prints Service

- Manuscript Podcast for convenient understanding

- Global attainment for your research

- Manuscript accessibility in different formats

( Pdf, E-pub, Full Text, Audio)

- Unceasing customer service

Track the below URL for one-step submission https://juniperpublishers.com/online-submission.php 